\title{
Between Village and Town: Small-Town Urbanism in Sub-Saharan Africa
}

\author{
Jytte Agergaard *(D), Susanne Kirkegaard and Torben Birch-Thomsen
}

check for updates

Citation: Agergaard, J.; Kirkegaard, S.; Birch-Thomsen, T. Between Village and Town: Small-Town Urbanism in Sub-Saharan Africa. Sustainability 2021, 13, 1417. https://doi.org/ $10.3390 /$ su13031417

Academic Editor: Tan Yigitcanlar

Received: 10 December 2020

Accepted: 25 January 2021

Published: 29 January 2021

Publisher's Note: MDPI stays neutral with regard to jurisdictional claims in published maps and institutional affiliations.

Copyright: (c) 2021 by the authors. Licensee MDPI, Basel, Switzerland. This article is an open access article distributed under the terms and conditions of the Creative Commons Attribution (CC BY) license (https:/ / creativecommons.org/licenses/by/ $4.0 /)$.
Department of Geosciences and Natural Resource Management, University of Copenhagen, Oster Voldgade 13, DK-1350 Copenhagen K, Denmark; qmv742@alumni.ku.dk (S.K.); tbt@ign.ku.dk (T.B.-T.)

* Correspondence: ja@ign.ku.dk

Abstract: In the next twenty years, urban populations in Africa are expected to double, while urban land cover could triple. An often-overlooked dimension of this urban transformation is the growth of small towns and medium-sized cities. In this paper, we explore the ways in which small towns are straddling rural and urban life, and consider how insights into this in-betweenness can contribute to our understanding of Africa's urban transformation. In particular, we examine the ways in which urbanism is produced and expressed in places where urban living is emerging but the administrative label for such locations is still 'village'. For this purpose, we draw on case-study material from two small towns in Tanzania, comprising both qualitative and quantitative data, including analyses of photographs and maps collected in 2010-2018. First, we explore the dwindling role of agriculture and the importance of farming, businesses and services for the diversification of livelihoods. However, income diversification varies substantially among population groups, depending on economic and migrant status, gender, and age. Second, we show the ways in which institutions, buildings, and transport infrastructure display the material dimensions of urbanism, and how urbanism is planned and aspired to. Third, we describe how well-established middle-aged households, independent women (some of whom are mothers), and young people, mostly living in single-person households, explain their visions and values of the ways in which urbanism is expressed in small towns. In conclusion, we discuss the implications of this urban life-in-becoming of small towns for urban planning, emphasizing the importance of the development of inclusive local governance. Ultimately, we argue that our study establishes an important starting point for further explorations of the role of the simultaneous production and expression of urbanism in small town urbanization.

Keywords: small towns; rural-urban in-betweenness; urbanism; Sub-Saharan Africa; Tanzania; sustainable urbanization; governance

\section{Introduction}

In the next twenty years, urban populations in Africa are expected to double [1], while urban land cover could triple [2]. Much of this growth is expected to take place in metropolitan regions and secondary cities [3]. However, urbanization in Africa is a multidimensional process displaying huge variations between nations and regions, based on physical, political, demographic, economic, and not least historical factors [4]. An important, but nevertheless often overlooked, dimension of Africa's urban transformation is the growth in small and medium-sized cities and towns [5], and the transformation of villages and small market nodes into small towns [6,7]. Many of these are rooted in rural regions, and while their continued emergence is resulting in shorter distances between rural and urban areas, many such emerging urban centres have not yet been defined as urban by national authorities [4]. It is the formation of 'urbanism' in these locations that is the focus of this paper.

Urban transformations and the plurality of urban forms have become crucial characteristics of our times. In recent decades, these processes have attracted a great deal of policy 
interest, in particular in relation to the New Urban Agenda and Sustainable Development Goal 11 (SDG 11) [8]. Many scholars have scrutinized the ways in which contemporary urban transformations have reached almost every corner of the world: a process that materializes in concentrated, extended and differential urban forms [9]. It has been questioned whether it is possible to capture these processes through conventional analyses of cities $[10,11]$. Some have argued that urban living has become an all-pervasive condition, and have maintained the need for an analytical distinction between rural and urban to be removed $[12,13]$. Others emphasize the importance of understanding urban centres as distinctive places for their residents. The implication of this is that urbanization shall be explored in particular locations with reference to the residents' own sense of place [9] and their historical contexts [14,15]. From this position, the 'urban' will be studied and theorized in its plurality, and from vantage points other than the metropolises [16,17].

This paper draws on these debates while it develops a particular focus on urbanism. In doing so, the paper contributes new perspectives to the reviving scholarship on Africa's small town development [18-25]. Our small-town focus is not an attempt to essentialize these locations. Rather, we approach transformations of small towns and their rural and urban spaces in the context of their contingent and context-specific social, economic and political pathways [23,24]. In the paper, we explore the ways in which small towns straddle rural and urban life, and consider how insights into this in-betweenness can contribute to our understanding of Africa's urban transformation. In particular, we investigate how urbanism is produced in small but fast-growing urban centres. In order to do this, we have researched two such small towns in rural Tanzania based on various types of quantitative and qualitative data collected during the past ten years [26-28]. Our analysis is structured around three main questions: (1) What characterizes the spatial expansion of these small towns, and how do households make a living in-between? (2) In what ways do these emerging urban locations appear as urban places? (3) How do residents identify with small towns as urban places, and how do they interpret the quality of urban life and aspire to it?

In the next section we develop a conceptual basis for the study of small towns and urbanism. We outline the many drivers of small-town growth, including the important role of transformations in rural economies and the involvement of migration and mobility. We also provide a sketch of the ways in which the study of urbanism can include both the material and social dimensions of small towns that are in processes of becoming. The third section describes two small towns, our engagement with researching them for the past ten years, and the data sources used for our analysis. In the fourth section, we present our analysis, organized in the form of responses to the three research questions presented above. Firstly, we emphasize how emerging small towns are essentially migrant places, and explore the declining role of agriculture. In particular, we examine the importance of farming, businesses and services for livelihood diversification among different population groups. Secondly, we show how buildings, transport and religious infrastructure display important material dimensions of urbanism, and how urbanism is planned and aspired to. Thirdly, we analyze the ways in which well-established and middle-aged households, independent women (some of whom are mothers), and young, mostly single-person households explain their visions and values of how urbanism is expressed in the two small towns. In Section 5 we discuss the ways in which urbanism is produced and expressed between villages and towns, and how it is formed by collective and individual practices, interpretations, visions and aspirations. Likewise, we consider how these insights on urbanism contributes to understandings of small town urbanization. In the final section, we reflect on the ways in which our analysis can contribute to a rethinking of governance systems in Sub-Saharan Africa. Ultimately, we argue that our study establishes an important starting point for further explorations of the role of the simultaneous production and expression of urbanism in small town urbanization. 


\section{Small-Town Urbanism}

The term 'urbanization' conventionally captures the process by which, in relative terms, more people come to live in urban areas compared to people living in rural areas. While this appears to be a straightforward definition, it nevertheless leads to some confusion. Firstly, because the two central terms-'rural' and 'urban'- have no universal definition. Secondly, because many locations are in the midst of transformations wherein they are not officially defined nor interpreted by their citizens as either clearly rural or urban. Many metaphors have been used to capture the mixed character of such locations $[17,21,29,30]$. The resulting rural-urban mixture of livelihoods and land uses have largely been conceptualized and researched in studies of suburbanization and peri-urban expansion, usually with reference to urbanization in and around major cities [31-33]. Such a metropolitan approach also applies to most studies of how urbanism unfolds as part of urbanization [34]. With a focus on emerging small towns in rural regions, it is our ambition to move beyond such a metropolitan gaze. In the remainder of this section, we will establish a conceptual starting point for the study of the role of urbanism in the ways in which urbanization is unfolding and impacting small town development.

The 'small town' is a context-dependent concept, and should be defined by a variety of indicators comprising material forms, socioeconomic functions, types of administration, and so forth [16] (see also the discussion in [23,35]). These diverse indicators could hardly be represented by one indicator, but one of the most-used measurements for small towns is population. Small towns are defined by the United Nations as urban agglomerations with a population ranging from 20,000 to 500,000 , by the United Cities and Local Governments (UCLG) as ranging from a few thousand to 50,000 , and by the EU as populations between 5000 and 100,000 [25]. In research and policy, small towns therefore refer to a broad range of urban locations [36-38]. This heterogeneity complicates cross-national comparison and policy making, which for Africa is further distorted by an almost-neglect of explicit policies for the promotion of small-town urbanization [25], with Rwanda [39] and Ethiopia [40] being among the few exceptions.

The important role of towns and secondary cities for Africa's structural transformation has recently been identified by developmental economists. It is argued that, compared to large cities, secondary cities and towns play pervasive economic roles as vehicles for rural-urban transformation and poverty reduction $[18,35]$. The ways in which changes in rural political economies have both direct and indirect effects on how rural-urban connections unfold are also captured in earlier studies of small town growth [41]. Such transformations, it is argued, are closely related with administrative and sectoral policies, not least agricultural policies which promote the global marketing of products and land. The latter have greatly affected the changes in agricultural productions, with impacts for both smallholder farming and the proletarianization of the countryside [42-45]. Together with the implementation of new forms of infrastructure, involving new communication technologies, these processes contribute to agrarian change in most of Africa [42,46].

The ways in which changes in the agrarian economy impact on small town development also intersect with wider demographic and spatial transformations. Migration abroad, to other rural regions, or to urban areas in search of employment is one of these trends, which often results in flows of remittances and new investments in both rural and urban regions [47-50]. Immigration to rural areas is of equal importance. In some areas, the availability of land, farming and employment provide commercial and/or livelihood expectations and opportunities for both individuals and households [51]. However, changes in the farming economy, e.g., in relation to plantation crops, smallholder schemes, new commercial crops [28,44], mining [19], investments in land [52-54], resettlement as part of land reforms [24], immigration and settlement into farming in response to policies promoting sedentary farming [55], and settlement in secure places during periods of political instability $[56,57]$ are different examples of how migration-to-settlement pathways develop and contribute to significant settlement in rural regions. Often, these processes of moving and settling are registered as rural-to-rural migration, not least because the 
bureaucratic definitions of places overlook the 'more-than-rural' in larger villages. Thus, in the very same locations, multiple reasons for and logics of moving into these places co-exist $[20,24,27,28]$; as highlighted by De Weerdt, the dynamics of rural-urban transformation and small town urbanization 'defy econometric destiny' [20]. This is further accentuated when we focus on the political roles of local leaders and citizens in small towns who are also important actors pushing for urbanization to happen [19]. Thus, there is a need for comprehensive explorations of the ways in which small towns become urban places, and how their residents become urbanites. Paraphrasing Reeves, who writes about the role of infrastructure, it is necessary to explore the 'affective forces' of small towns, including the 'hope' they inspire in people [58].

One dimension of the broadening of the research agenda for small town urbanization is the development of an explicit focus on urbanism. Commonly, the term 'urbanism' refers to the ways in which people interact with the built-up environment. In Africa, this includes many different realities, and according to Simon, it may not be very useful to define the term further [59]. Urbanism should thus be studied as contingent and process-oriented, and should move beyond - as Simon suggests-characterizations of urban practices to include urban residents' lived experiences and identities [59]. In this way, urbanism is closely associated with the process of 'becoming urban', which-according to Anh et.al.-implicates the ways in which migrants settle in the city, and how they integrate into the urban fabric [60]. Becoming urban involves multiple, often overlapping dimensions, including the bureaucratic and legal contexts, livelihood practices, identities (whether self-expressed or externally reified), social and cultural behaviour, and social networks [60]. Thus, explorations of urbanism include studies of social practices associated with what urban environments provide, and how these practices are expressed materially and socially. Although size does not define the small town, smallness may nonetheless connote certain ways of acting, self-images, structures, senses of place, and aspirations [16]. Thus, studies of small town urbanism should also pay attention to the importance of smallness, the proximity to rural areas (and rural living), affordability, and incremental growth. The preceding discussions will form the conceptual framework for the rest of the paper, where we seek to capture both the rural-urban betweenness of small town urbanization, and the urbanism that is produced in and with reference to this process.

\section{Materials and Methods}

Tanzania is one of Sub-Saharan Africa's most rapidly growing and urbanizing countries, with an annual urban growth of 5 percent [61]. Large and secondary cities are expanding, but much of this substantial growth stems from the densification and expansion of small towns, including those that have not yet been incorporated into the official urban hierarchy [62]. Since the early 2010's, we have partnered with Tanzanian researchers in collaborative research on rural-urban transformation in four formerly-rural areas that have all been experiencing that their central villages have transformed into small towns. Importantly for our research, this development has not been promoted, either economically or administratively, by regional or national governments (https:/ ign.ku.dk/english/rut/). In this paper, we draw on this research and earlier descriptions of rural-urban transformation in two of these small towns, Madizini and Ilula [25,26,28,63-65]. Figure 1 shows the location of the two towns in Tanzania. 


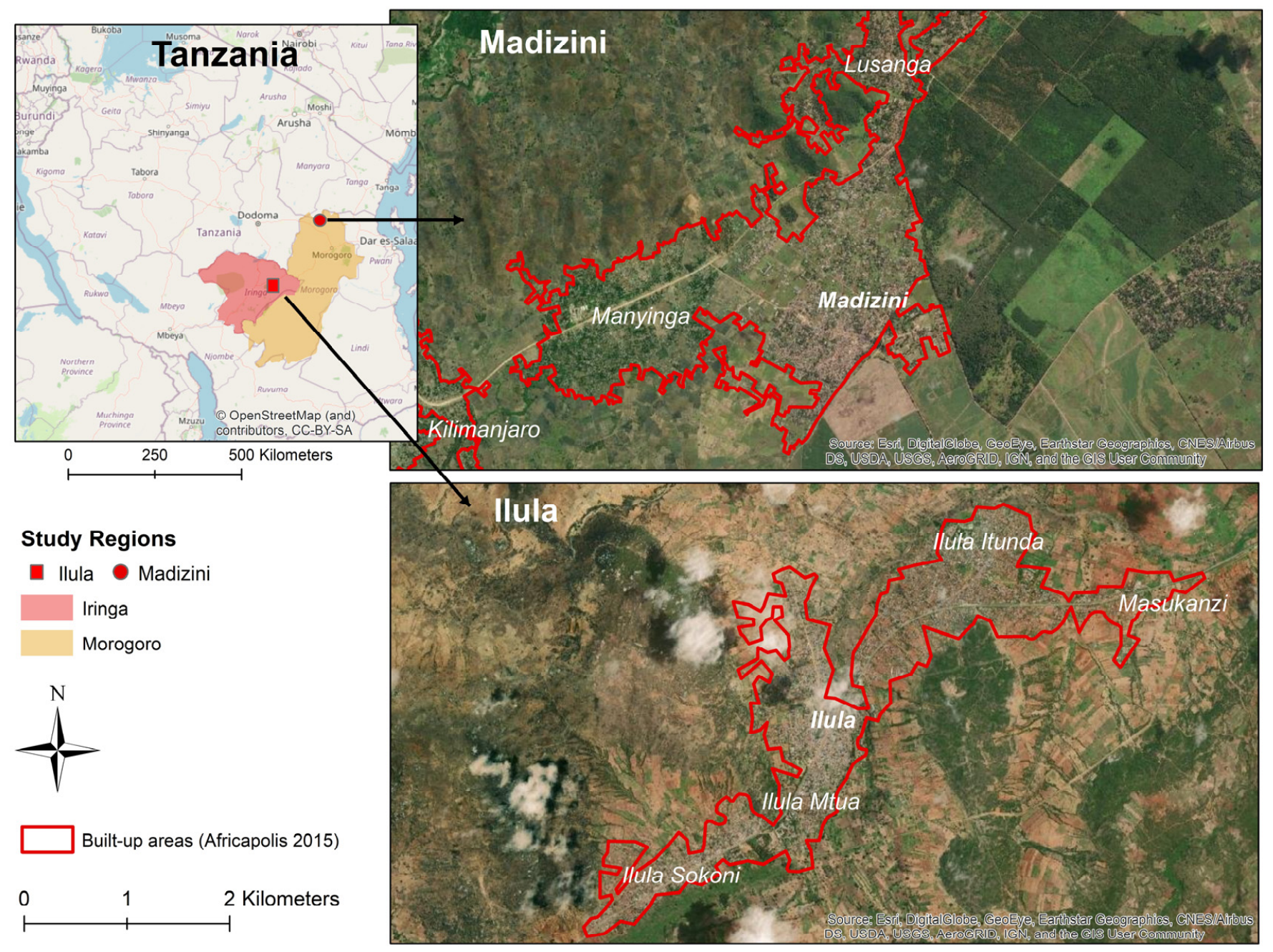

Figure 1. Maps showing the location of the two study sites and their regions in Tanzania (upper left), and the two small towns, Madizini $\left(6^{\circ} 08^{\prime} 24.49^{\prime \prime} \mathrm{S}, 37^{\circ} 38^{\prime} 11.71^{\prime \prime} \mathrm{E}\right.$ in Mvomero District) and Ilula $\left(7^{\circ} 40^{\prime} 53.36^{\prime \prime} \mathrm{S}, 36^{\circ} 02^{\prime} 15.36^{\prime \prime} \mathrm{E}\right.$ in Kilolo Distict) (to the right). The satellite image dates are 7th February 2017 and 1st April 2015, respectively. ArcGIS Image Source: Esri, DigitalGlobe, GeoEye, Earthstar Geographics, CNES/Airbus DS, USDA, USGS, AeroGRID, IGN, and GIS User Community.

In Table 1, we summarize a comparative overview of the main characteristics of the two urban centres. Their population sizes were estimated based on data that are almost a decade old, and we assume that the census figures for 2022 will be much higher (see also Section 4.2). Hence, according to population sizes, both locations could be interpreted as small towns (see Section 2). We also show that specialized agricultural production and the related needs for processing, marketing and labour have been instrumental in driving the initial growth. In addition, Ilula's location around the main TanZam highway is a related driver, and continues to be so. However, Madizini and Ilula have experienced new economic drivers contributing to, and to some extent replacing, the initial ones. These factors will be explored further in the following subsection, and we will return to the implications for sustainable development of the mixed form of governance in which township status is announced but not implemented. 
Table 1. Characteristics of Madizini and Ilula, based on the authors' observations, focus-group discussions, and key informant interviews.

\begin{tabular}{|c|c|c|}
\hline & Madizini & Ilula \\
\hline Estimated population & $14,168(2012)$ & $22,957(2012)$ \\
\hline Geographical location & $\begin{array}{l}\text { Located on rich and predominantly rain-fed } \\
\text { agricultural land }\end{array}$ & $\begin{array}{c}\text { Located amidst large land tracts, huge variation } \\
\text { in land quality }\end{array}$ \\
\hline Infrastructural location & $\begin{array}{l}\text { Until recently located off the road system. } \\
\text { Approximately } 100 \mathrm{~km} \text { north of Morogoro Town } \\
\text { (regional headquarters) }\end{array}$ & $\begin{array}{l}\text { Located on the TanZam (Tanzania-Zambia) } \\
\text { highway. Approximately } 50 \mathrm{~km} \text { south of Iringa } \\
\text { Town (regional headquarter) }\end{array}$ \\
\hline Physical expansion & $\begin{array}{l}\text { Mushrooming from the small village around the } \\
\text { old factory, recently eating up the open space } \\
\text { between neighbouring villages }\end{array}$ & $\begin{array}{c}\text { Agglomerating town: open spaces between } \\
\text { villages have continuously been transformed } \\
\text { into build-up land }\end{array}$ \\
\hline Densification & $\begin{array}{l}\text { High density radiating from the early } \\
\text { 'urban' centre }\end{array}$ & Medium density-more 'urban' centres \\
\hline Initial drivers of growth & $\begin{array}{l}\text { Sugar cane plantation, factory and out grower } \\
\text { scheme }\end{array}$ & $\begin{array}{l}\text { Transport corridor, tomato production and } \\
\text { tomato market (religious centre) }\end{array}$ \\
\hline New drivers of growth & $\begin{array}{l}\text { Tree factory, dairy farming, businesses and local } \\
\text { service centre functions }\end{array}$ & $\begin{array}{l}\text { Tomato factory, 'road stop economy', businesses } \\
\text { and local service centre functions }\end{array}$ \\
\hline $\begin{array}{l}\text { Administrative } \\
\text { transformation }\end{array}$ & $\begin{array}{l}\text { Township status announced in 2002. Very slow } \\
\text { transformation towards township (urban) } \\
\text { status, reluctance of district authorities to } \\
\text { devolve line offices, resources etc. }\end{array}$ & $\begin{array}{l}\text { Township status announced in 2006. Slow } \\
\text { transformation towards township (urban) status, } \\
\text { recently the district has agreed to support the } \\
\text { establishment of some formal structures }\end{array}$ \\
\hline
\end{tabular}

The population data are estimates, as the urban parts of the formal villages do not constitute independent enumeration areas in the 2012 census [65].

We were first introduced to the Madizini and Ilula cases in June and July 2010. Initially, our focus was mainly on the processes of rural transformation and their effects on rural households. Later, our data collection shifted towards achieving a better understanding of the emergence and role of the urban parts of these growing villages. This research adopted qualitative, quantitative and spatial analyses. The qualitative methods included semi-structured interviews and focus-group discussions. Pre-designed checklists of questions guided the interviews with key informants and focus-group discussions. The key informants included district officials; village, town and township leaders; leaders of major financial institutions; and residents of the growing villages and small towns who were knowledgeable about historical and recent trends in their political, economic, demographic and spatial development. Based on village registers, focus-group discussions were conducted in each study site. In-depth interviews using historical timelines and narratives were used to identify the critical historical events (social, economic and political) that have influenced the major turning points in the development of each of the small towns. Furthermore, qualitative interviews were conducted, in both 2014 and 2017-2018, with long-term residents (both indigenous and migrants), more recent settlers, and temporary migrants (and multi-locals) of different ages and genders in order to understand the attractions of these urban centres to them, and their perspectives on these small towns as urban places. The informants for the 2014 qualitative interviews were selected from household lists provided by sub-village leaders. In 2017-2018, the informants were identified from a household survey conducted in 2016. The Rural-urban Transformation household survey was based on a stratified random sampling of households in selected segments representing the variation in housing density within the two small towns. This resulted in a proportional (7.6\%) sample population of 144 (Madizini) and 323 (Ilula) household questionnaires, respectively (see Appendix A). As part of the spatial analyses, the centres were mapped in various ways, by: (a) identifying and locating different types of housing, businesses, services etc., (maps and photos); and (b) documenting the spatial expansion of the built-up areas through analyses using a combination of Landsat and Sentinel images, Open Street View Map and Google Earth Pro. 


\section{Economic, Material and Social Dimensions of Small Town Urbanization}

In this section, we present our data analysis, and consequently attempt to answer the three research questions. Thus, the section is divided into the following three sub-sections: Livelihoods in-between, Material dimensions of urbanism, and Aspirations for urban living.

\subsection{Livelihoods in-Between}

Emerging small towns are essentially migrant places. This is recognizable from Table 2, which shows the weight of migrant households: $83 \%$ in Madizini and $49 \%$ in Ilula. Immigration is a continuous process and, as we will show in this section, includes different population groups that engage with small town development in various ways. The starting point for our analysis of livelihoods is that these are based on both rural and urban activities. This is shown in Table 2, which presents data on the main occupations of the heads of households in Madizini and Ilula. Common for the two small towns is the continued importance of agriculture; in Madizini, $49 \%$ of the household heads mention agriculture as their main occupation, compared to $70 \%$ in Ilula. However, despite the continued importance of farming, the role of farming is dwindling. Many other occupations are available, such as businesses, government jobs, and other employments that often-in combination-form livelihood diversification. In this sub-section, we will outline how this livelihood diversification is constructed between rural and urban opportunities. For this, we focus on three interconnected features: (1) the separation of farming and residence, (2) the dynamics of multiple sources of income, and (3) the role of the transient population.

Table 2. Occupations of the heads of households, based on the Rural-urban Transformation household survey, 2016.

\begin{tabular}{|c|c|c|c|c|c|c|}
\hline \multirow[b]{2}{*}{ Main Occupation } & \multicolumn{3}{|c|}{ Madizini $(n=143)$} & \multicolumn{3}{|c|}{ Ilula $(n=323)$} \\
\hline & Percentage & $\begin{array}{c}\text { Locals } \\
\text { (No.) }\end{array}$ & $\begin{array}{l}\text { Migrants (No.) } \\
\text { Mean Year of } \\
\text { Arrival }\end{array}$ & Percentage & $\begin{array}{l}\text { Locals } \\
\text { (No.) }\end{array}$ & $\begin{array}{c}\text { Migrants (No.) } \\
\text { Mean Year of } \\
\text { Arrival }\end{array}$ \\
\hline Agriculture & 49 & 12 & 571996 & 70 & 120 & 1051998 \\
\hline Business & 21 & 5 & 252003 & 11 & 15 & 202005 \\
\hline Government & 5 & 1 & 62003 & 5 & 5 & 121999 \\
\hline Other jobs & 22 & 5 & 272000 & 11 & 19 & 162006 \\
\hline Other & 4 & 1 & 4 & 3 & 6 & 5 \\
\hline Total & 100 & $24(17 \%)$ & $119(83 \%)$ & 100 & $165(51 \%)$ & $158(49 \%)$ \\
\hline
\end{tabular}

Locals: denotes that the household head was born in the same location as that of current residence. Migrants: denotes those who were not born in their current place of residence.

For the many households that are continuously and directly involved in farming, their locations of farming and residence are increasingly separated when farmland is parcelled out for housing. This process is pronounced in Madizini, and started taking form when a processing factory and out-grower scheme were started south of Madizini in the late 1950's. However, it was the establishment of a new factory in the mid-1970's that marked Madizini as a sugar-cane-growing area. The settlement in and around present-day Madizini began in the early 1980's, when the sugarcane out-grower scheme progressed. At that time, workers in the plantation and factory started buying small plots of land to produce their own sugarcane. Some bought land in the surrounding small villages, though seldom enough in one place. Thus, a pattern evolved of many farmers building a house in the Madizini area, where they established themselves as out-growers. However, their land, often small patches, was dispersed at a distance of thirty minutes to two hours by bike from their houses. Others first moved to one of the surrounding villages, where they obtained land and established themselves in Madizini at a later stage. Thus, among the residents who arrived before the 2000 's, we see a pattern of high levels of residential mobility and incremental housebuilding. From the mid- to late-2000's, many out-growers stopped 
producing sugarcane, and some reduced their landholdings and started to cultivate staples such as maize and rice both for their own consumption and for sale.

The migrant households that arrived from the mid-2000's onwards were less directly engaged in farming see Table 2. In the case of all households, businesses and other types of employment have become either the primary or secondary source of income. Of the 69 heads of households who mention agriculture as their main occupation, 64 per cent are also involved in some sort of business. When we add to this the occupations that other household members engage themselves in, we see a strong pattern of income diversification. One indicator of these activities can be derived from the official list of registered businesses, shared by the local representative of the Tanzania Revenue Authority (TRA). In 2017, Madizini had nearly three hundred registered businesses. Around $25 \%$ of these were directly related to farming, such as the provision of machinery, fertilizer, maize-milling, and transport, etc. However, the remainder (225 businesses) we interpret as being part of a local service economy. These businesses include twelve hair salons, ten bicycle shops and repair shops, seventeen bars, twelve restaurants (including three hotels and two more posh hotels that have been registered since), and a range of different shops. In addition, Madizini hosts three commercial banks with cash machines. Madizini provides meat, vegetables and other groceries not only to its own residents but also to the surrounding villages, through both permanent stalls and its biweekly market. The qualitative interviews confirmed that many more individuals are engaged in unregistered petty trade, such as buying three or four bags of maize in Morogoro and selling small quantities to the many households that do not have the finance or space to store food (household interviews, 2011).

Thus, for many households, rural and urban livelihood activities intersect, while others rely on business, either as the owner or as an employee. The two to four thousand workers who are usually engaged on a temporary basis during the cane-cutting season form a group on their own. These labourers are mainly recruited through national advertisements, and are hosted in one of the seven labour camps located in the Madizini area. These camps offer little more than a room, water, and simple toilet facilities, and the majority of the men have to cook and wash on their own. This drives an economy of other temporarilyemployed persons, including young men and women in the many bars, guesthouses and 'beer' clubs. Interestingly, 17 percent of the households in Madizini report receiving an income from renting out rooms: some have one to three spare rooms for rent in their houses, but others have erected separate buildings with single-room apartments for rent, in some cases more than ten such rooms. The temporary residents who occupy the many rooms include widowers and independent women, or second wives with children. Many of these women have temporarily been left by their male breadwinners, who work as-for example-drivers. However, among the renters, we also find members of rural households who are looking for work and/or comfort and services. This could be schooling for children, health facilities, or young people trying their luck in the expanding urban economy; some of these are even building a second house on their own.

Ilula is experiencing some of the same transformations as Madizini. However, agriculture and the handling of agricultural produce play a more central role cf. Table 2. Ilula owes its form to the TanZam Highway, stretching east to west and extending north and south, where villages and farmland are included in the built-up area for the historical development of its built-up area, see Appendix B. Built in the early 1970's and upgraded in the 2000's, this highway is an extended two-lane tarmacked road connecting the port city of Dar es Salaam with landlocked Malawi and Zambia. However, the originally sparsely populated area through which it passes started to grow when workers arrived from many regions of Tanzania to work on a Greek tobacco farm established in the 1940's. In 1974, a village government was established as part of Tanzania's villagization program [28], and subsequently maize took over as the dominant crop. With the introduction of a new variety of tomatoes in the early 1990's, tomato production and retail became the backbone of Ilula's farm economy. In present-day Ilula, the tomato market has a long season in which retailers purchase tomatoes, which are packed and shipped by truck to vegetable 
markets in Morogoro and Dar es Salaam, and to neighbouring countries. In 2006, Ilula was declared a township, but so far full status has not been granted, and authority has not been transferred from the Kilolo District. Thus, Ilula's transition from 'village' to 'town' is still ongoing. Compared to Madizini, migration to Ilula from other regions is of less importance to explain the separation of farming and residence, and the location's emerging urban character. These processes are more the effect of immigration from the surrounding villages. This process started in the 1990's, but intensified in the mid-2000's, when the diversity of livelihood activities within the small town expanded.

Although it is embedded in a rural economy, Ilula also provides a much wider set of livelihood activities. This is evidenced by the fact that 56 percent of the 225 households that reported agriculture as their main livelihood activity are also involved in some sort of business. This is also illustrated by an analysis of the 2016 list of officially-registered businesses. Of the 358 registered businesses, 13\% (46) are labelled 'retail' (see also [26]). The packing and shipping of tomatoes is big business in Ilula, and it provides employment for many young men during the season. Another thirty businesses are directly related to farming, providing seeds, milling, and machinery, etc. However, the remaining businesses indicate the existence of a diverse local service economy. Compared to Madizini, the number and diversity of shops is much greater, with 52 shops selling clothing and shoes, 32 beauty salons and hairdressers, 42 grocery stores, 27 liquor stores, and 28 guesthouses and restaurants. These service not only local residents and people in the rural hinterland but also Ilula's sizeable 'road economy' as well, as illustrated by the 25 businesses in motorbike vehicle servicing and welding. Of the many trucks and busses that pass Ilula each day, a considerable number stop over to buy services for the trucks, the truck-drivers, and travellers (including servicing female company). Ilula is one of five 'hotspots' in Tanzania where the North Alliance provides health care (and education) to mobile workers and the communities they interact with, in particular in relation to reproductive health and HIV / AIDS (https: / / www.northstar-alliance.org/our-clinics/). We visited their recentlyinstalled Blue Box Clinique in 2017, and learned about the challenges they are facing because sex-workers are visited not only by the truckers, but also by young temporary workers in tomato-picking and retail, as well as adult farmers seeking entertainment when they have had a lucky strike in selling tomatoes (interview, May 2017; see also [66]).

Hence, just as in Madizini, rural and urban livelihoods intersect. However, Ilula provides many more formal employment opportunities, for example, in its two hospitals, health centres, police station, eleven banks and other financial institutions, and its many primary and secondary schools, etc. In Ilula, the variation in non-rural income-generating activities is greater than it is in Madizini, but as with the latter, it is hard to judge the numbers, because the high inflows of temporary workers vary throughout the year. Just as in Madizini, many households rent out rooms (15 percent of households mention having rental incomes). In addition, an increasing number of young people are moving between various temporary income-generating activities involving short-term employment, for example, agricultural work in neighbouring districts, employment in Ilula's businesses (including various steps in the production chain of tomato boxes for different markets), local transport such as motorbikes and bajajis (tricycle scooters used to transport passengers), and hawking in the streets, etc.

\subsection{Material Dimensions of Urbanism}

In the preceding subsection, we outlined the ways in which livelihoods in the two small towns are characterized by diversification into business, salaried employment, and hawking. We have shown that farming, in combination with business, is very pronounced in Ilula, but also of importance in Madizini. However, for other households (50 percent in Madizini and 30 percent in Ilula), farming is not the dominant source of income. We also stated that few households farm within the space of the town area, meaning that these two small towns have become dominated by residential housing, buildings for businesses and services, and other infrastructure. This is illustrated in Figure 2, below, in which the images 
numbered ' 1 ' in Ilula and Madizini show the unplanned and dense built-up areas that make up the current centres of both small towns. The other images illustrate less densely built-up areas, as well as the variation in the settlement processes. In the following section, we will refer to these images when we further explain how urbanism is materialized in both small towns.

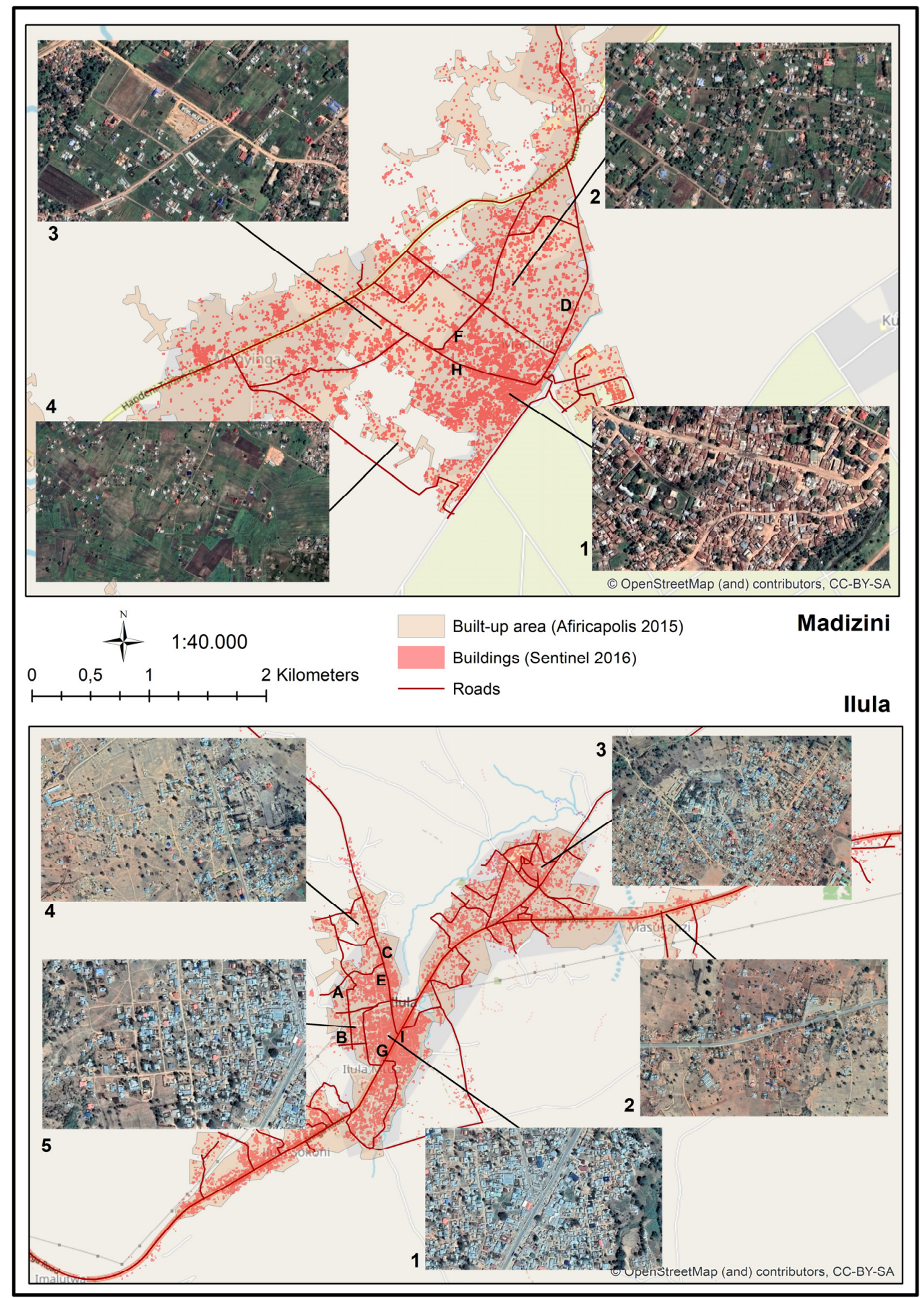

Figure 2. Settlement structures and patterns in Madizini and Ilula. The capital letters (D, F and H in Madizini; A, B, C, E, G and I in Ilula) refer to the photos in Figure 3. The inserted images are screenshots from Google Earth, dated 19th February 2020 (Madizini), and 30th October 2019 (Ilula). 


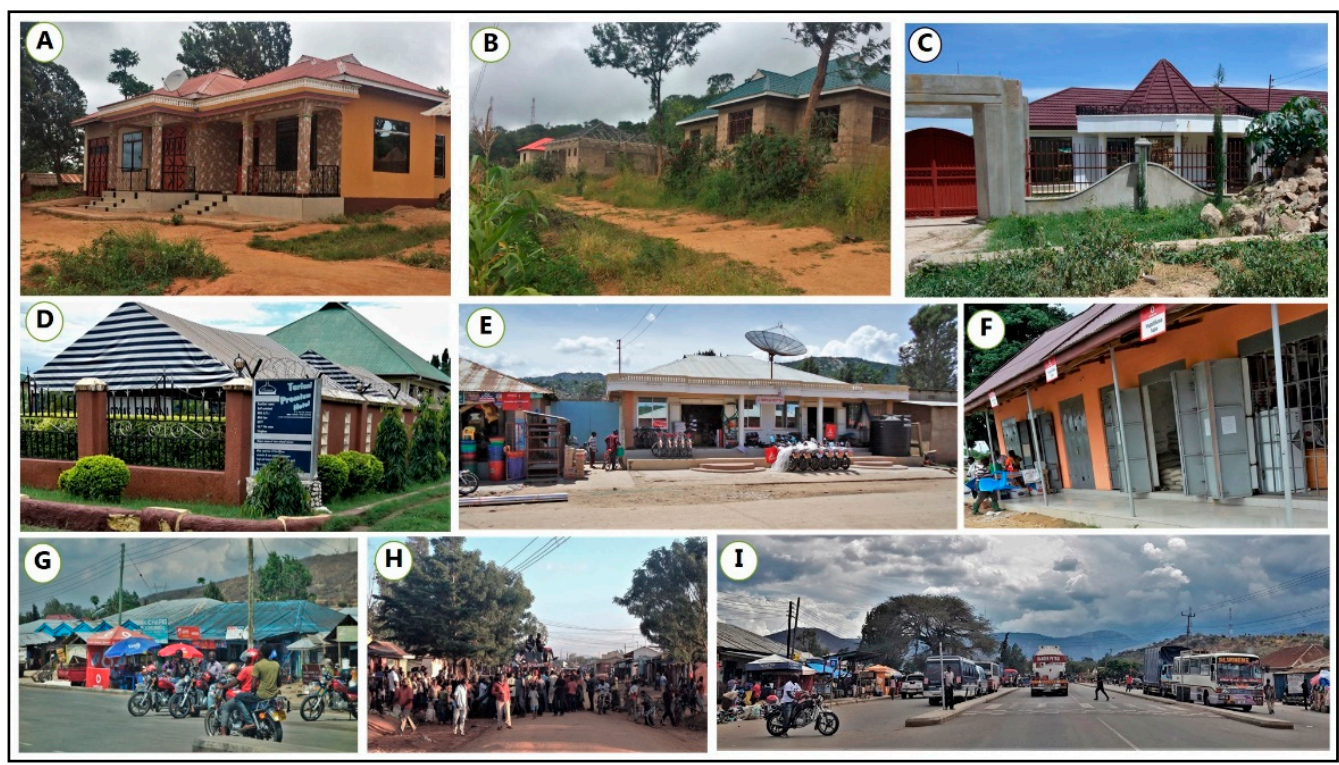

Figure 3. 'Small town' images from Madizini (D,F,H) and Ilula (A-C,E,G,I); in order to locate the photos, see Figure 2. The photos were taken by the authors.

In this sub-section we focus on how the dawning urbanism is expressed in the built-up environment. As mentioned above, and as is recognizable from Figure 2, Ilula consists of several old villages that have merged into a single unit because of the continuous construction of houses and structures in the spaces between them (see also Appendix B). Accordingly, we find old village-like layouts of houses in various locations. A similar process is underway in Madizini, where the built-up area is expanding from the south towards the new road, and where the villages of Turiani (called Kilimanjaro on the Madizini map, Figure 1) and Lusanga have linked up with Madizini. However, in the two centres (images 1), many types of houses and buildings are evident, from simple shack structures to permanent houses made of clay-plastered walls and zinc roofs to modern houses made from baked bricks and concrete. This includes modern glass facades, and examples of old structures being replaced by modern ones in concrete and steel that are more suitable for business. Both centres also have modern hotels offering city-like services, with three of them in Madizini being located around the new road (Figure 3, image D). Outside the centres, we find 'villa-like' compounds located in more planned grids of roads, in both Madizini (image 2) and Ilula (image 5), but pockets of modern housing are also found along the main roads Figure 3, images A, B and C. In Madizini, new shopping arcades (more than fifty individual floor areas with metal fronts) were established in 2016-2017 around the junction shown on image 3 . These add to those located in the centre, but are also designed to serve the new bus stop for regional bus routes. Being located along dusty roads Figure 3, images E and F, these diverse constructions resemble peri-urban Dar es Salaam more than a village.

The emerging urbanism in Madizini and Ilula is also shaped by the expansion of transport infrastructure Figure 3, images G, H and I. In Ilula, the many passing buses and trucks play their part in this. However, the emerging transport infrastructure is also formed by how villages in the hinterland are increasingly being connected to Ilula with minibuses and upgraded roads. Many passengers travel to Ilula as their destination, while others change buses to go to Iringa or Dar es Salaam. During the 2010s, bajajis and motorbikes also started to operate within the space of Ilula, while much of the local transport in Madizini is managed by bicycles. However, Madizini is also well connected by extra-local bus routes, and as the main road connecting the town to the Morogo-Dodoma highway has been tarmacked (2018), journeys are becoming faster, and transport is becoming more frequent. Thus, the establishment of transport infrastructure, including bus lanes reserved 
for passenger drop-off locations, contributes to the urban feeling and 'buzz' of these small towns.

These material dimensions of urbanism are further maintained by the religious infrastructure. In both towns, Catholic missions and hospitals were established prior to the small-town development. In both cases, the initial church buildings and hospitals wer further developed to cater for an increasing, and also wealthier, population [67]. In Ilula, a Lutheran mission with a church and hospital was also established. Later, in 1998, an orphan program initiated by one of the church communities was established to provide children of Ilula-Itunda who had lost their parents to malaria, TB, or HIV / AIDS with shelter and schooling (located north of the main road in Ilula; see Figure 2, image 1). In Madizini, the Roman Catholic Church is constructing a cathedral and structures to establish a mission. In 2011, we visited eight additional well-established religious communities with permanent structures, seven of which were within the old settlement (Madizini, see Figure 2, image (1). Thus, even though they are small in size, both small towns provide a social and material 'topography of faith' [68], which is strongly promoted by national and international missions, as well as community centres for urban residents, thus contributing to the material dimension of urbanism.

The discussions with the local leaders and opinion-formers in the two small towns confirmed the importance of these structures and how they interact with people's visions and practices. The construction of city-style houses and businesses, together with the enlargement of modern transport infrastructure, testify to the huge expectations of the urban to come. The informants explained how they have struggled to persuade district governments to hand over full township responsibilities to the small towns. Officially, such transfers should be based on the development of material, economic and political urban structures [28]. In both small towns, the locations and construction of bus stations, which started in the late 2000's, are iconic examples of this. Stories were told of how aspiring citizens pressed for bus stations to be located close to or on their land, with the expectation that this would raise the degree of urban expansion and thus increase land prices, as well as boosting trade with their many users. In Ilula, local leaders were keen to draw urban development away from the centre, and decided to construct a new bus stop for regional bus routes at the eastern end of the town Figure 2, image 2. The owner of an old hotel, located in Ilula Sokoni, where the regional buses used to stop Figure 2, image 1, followed up on this, and invested in a plot of land next to the new bus station, where-in order to stay in business - she established a restaurant and a petrol station. Interestingly, however, urban development towards the east has been very slow: buses still make a stop in Ilula Sokoni, and business has been much less than the hotel owner had expected. Another example of the ways in which local leaders are trying to influence the government to transfer their town to full township authority is the decision to set aside land for a new township hall north of the town centre and north-east of the road leading north Figure 2, image 4 . In 2017, this was followed up by tarmacking a stretch of 1.5 kilometres of the road leading from the centre to the future townhall site. Following these initiatives by the local government, the amount of recently-established modern housing rapidly increased based on investors' expectations regarding future urban development see Figure 3, image C. Thus, local leaders and citizens have, in various ways, exercised their agency in materializing the small towns to become urban.

\subsection{Aspirations for Urban Living}

Adding to the preceding examination of the ways in which urbanism is produced, this subsection explores how residents express their aspirations for urban living, and how they identify with these small towns as urban places. As illustrated above, the construction of infrastructure and modern housing signifies the hopes for changes that are pushing the rural to become urban. This is confirmed by conversations with residents in both Ilula and Madizini. Angelina, a 26 year old woman engaged in businesses in Madizini, explained how she aspires for the place to become more urban. As she adds, this will be achieved 
through better planning and the construction of proper roads and recreational spaces, and the privacy of individual plots (April 2016). Ally, a married man in his thirties who is now living in Ilula, also referred to roads and orderly infrastructure as being what makes a place urban: "I have been living in many places, and I have found that proper roads is what makes people want to settle (add to this) that here in Ilula you also have services like the hospital ..." (May 2017). Others refer to their previous homes in villages as being rural, and Madizini and Ilula as providing a feeling of being urban. Many residents refer to the roads and access to electricity and water as important drivers for people starting to build 'urban' houses. Devota and Nelson, a couple in their thirties who are engaged in both business and farming, are building a modern house in Ilula just where the tarmacked road ends, as they expect development to move in this direction. The wife, Devota, said that "Ilula is a place that grows, and it is still affordable to get a plot and build a house" (May 2016). Furthermore, Morgan and Tiby, he in his early fifties and she in her early thirties, recently finished the garden of their modern house, just on the outskirts of Ilula, where they have now moved permanently. He is proud of the house and happy with the location, from which he can run his tomato business, and she likes the modern facilities, though she complains about the distance to friends and family (May 2016).

Asman and Asha, now in their late 50's, who had lived in Dar es Salaam most of their adult lives, explained how, upon their retirement-he from the immigration authorities and she from the police-decided to return to the Madizini area to build their own house. Although they had inherited a small plot of land outside the small town, they preferred to buy land in Madizni itself. This made it possible for them to continue their urban lives, but at much lower costs for a sizeable plot and modern house, where they are able to combine their savings, pensions and income from maize and paddy production (August 2011). Lydia, who lives in a modest house in Ilula, explained how people from Dar es Salaam are investing in plots and starting to build big houses in central places, and she pointed out a huge construction site next to her own house, describing how the owner, a young man, comes at weekends to oversee the construction (May 2017). Richard is an example of a man in his late twenties from a village in the rural hinterland who, after an unsuccessful attempt to do business in Iringa (the regional city), succeeded in establishing a shoe business in Ilula. Reflecting on his success, he explained that the start-up costs in Ilula are much lower, while his ability to commute between the town and his home village, where he still has a farm, has reduced the risk of his investment. Now, he is renting a room in town, in addition to keeping the house in the village (October 2016).

Modern housing thus signifies the urban-in-becoming, not only to owners but also to observers like us. However, urban living in Ilula and Madizini is also expressed in other ways. One recurring point for people who have left their villages to live in the centre is how to get used to new acquaintances they do not know. For Michael and Elizabeth, both in their forties, who moved to Ilula five years ago to manage both farming and business, it has been difficult to get used to living among a mixture of people, most of whom they do not know (April 2016). Peter, who is in his forties and runs a small clothing business, explained that he feels he cannot trust people in the town: "in the village we could give credit, and we would know that people would return the payment when they got money, here they just disappear, and you never see your money" (January 2017). Kristina and Levi, a couple in their forties, on the other hand, embrace the mixture of people that the urban living provides: "it is a change to live here, and you have to do things yourself. But many different people come to your house with different education and background, and you learn about different ways of living" (January 2017).

For many residents who have left a village, the social distance and anonymity thatcompared with their old homes-characterize Madizini and Ilula is, for them, an important marker of the urban-in-becoming, and something they aspire to. In particular, independent women and young people explicitly emphasize this as an important quality of small-town life. Tausi, a deserted woman in her mid-thirties who is living in a rented room in Madizini surrounded by other independent female-headed households with children, explained: 
"Here, I can provide for my children: they can go to school, and sometimes I can do trading and other times take up farming jobs ... and we are safe here" (May 2016). It is well known that independent women living on their own, because they are widowed, have been deserted, or are managing as a second wife, face economic and social difficulties when living in villages in Tanzania. In addition to this, they are often treated with suspicion, while the small towns, by contrast, provide them with some opportunities. Settling in an urban area makes it easier to deal with social and cultural restrictions. However, as Tina - who is 25 years old and moves between jobs-explained, she is the target of a lot of gossip because of what she is doing. Again, for others who have previously lived in urban locations, such as Iringa, Morogoro or Dar es Salaam, small towns are associated with social control, just like living in a village. As a young girl called Savior said: "In Ilula there are few places for young women to go if she wants to avoid rumours starting about her. The only OK place to go is the FM lodge (the new hotel)" (January 2017). With reference to Ilula, this issue is discussed at length in [66], in which the authors describe women's explanations of the ways in which becoming a mother can make them respectable and free them from the suspicion and condemnation of others.

Young men and girls usually value life in these semi-urban spaces. Willy, who is in his late twenties, has access to a small plot in his village, but this is not enough to support him and establish a family; by sharing a room with three other people, he can stay in Ilula on a low budget and save up money to establish something for himself in the future. Several young people go to the larger towns by bus to buy stock to sell, while others are simply sent goods by their relatives. But these are precarious businesses. Shedrack, like many others, is also trying his luck in trade, but most often he relies on driving someone else's bajaji for a living. Although he complains about his problems in saving money, he values the urban buzz, and dreams of becoming a musical performer. Other young people expressed their urban expectations as the owner, employee or customer of one of the many beauty parlours. After working in a hair salon in Iringa for four years, Adrian, a man in his late twenties, returned to open his own salon in Ilula, where it is much cheaper, and where many young people want to look smart (urban). The salons have become important meeting places where young people share their visions about modern life, music and fashion, as well as the hundreds of photographs of them posing alone or with others that are posted on social media each day. Thus, young people's identification with the urban is expressed in symbols that are different from those that pertain to the older generation. However, as Asha, a young woman of 21 , noted with reference to the precarity of many young people living in Madizini: "The youth is the workforce of the nation. Thus, if you live in a place where there is no job and no business, you are weakened and start to do things that are not socially acceptable such as smoking, drinking and engaging in prostitution" (April 2016). This comment points to one of paradoxes of living in these in-between spaces, where urban living and urbanism are being formed; on the one hand, although diverse, these spaces provide opportunities for and visions of living better lives; on the other hand, the young do not receive much support or guidance in moderating these opportunities and visions.

\section{Urbanism between Village and Town}

Our parallel study of two small towns in Tanzania has shown that, although their transformations started from rather different positions-e.g., biophysical characteristics, rural dynamics, demographic histories and infrastructural positions-they have come to share many similarities. The preceding analysis was focused on three dimensions of how urbanism is produced and expressed. Firstly, we showed how the small towns have become residential areas with mixed livelihoods, and are greatly influenced by migration from surrounding villages and from further afield. In many ways, these small towns are migrant places. For many households, farming continues to be an important source of income, but often in combination with business activities. Other households are mainly engaged in business activities and services. Our analysis revealed an impressive variation in the businesses registered, testifying to the range of services that these small towns provide, 
as well as the diversity of the available occupations. Secondly, we described the spatial extensions of the built-up areas and infrastructure. These transformations are the outcome of two coinciding processes: the planning efforts by local communities, and the wider aspirations of individuals and groups for urban transformation to happen. This is expressed in the establishment of bus stations and setting aside land for public purposes, such as the construction of paved roads. The ultimate motivation of these efforts is to persuade district governments to support and endorse an administrative transition to township status. The profound transitions in housing are, however, significant expressions of individual visions and ambitions for the creation of urban environments. Overall, we observe the ways in which these transformations resemble the material form that is also significant in the peripheries of Tanzania's large cities. Thirdly, we outlined how these aspirations for living urban lives, and to benefit from urban livelihood diversification, flexibility and services, are expressed. Importantly, however, such aspirations vary significantly between social groups, gender and generations, e.g., stable couples, independent women, and the young.

In our analysis, we showed that affordability, flexibility, privacy, and diverse economic and social opportunities are features that informants of all types emphasize when they are asked to evaluate the qualities of small towns. These characteristics are also positively appraised by those of our informants who had returned to small towns after giving up trying their luck in larger cities. However, these features are not weighted equally by all. In our view, in-between livelihood opportunities and low land prices are important drivers for the more mature people when they are deciding to settle in small towns. For independent women, flexible employment arrangements and access to basic services, along with the absence of social control, are the determining factors. For young people, small towns provide them with the prospect of establishing their independence and a way of life, which is otherwise-in many cases-forbidden to them in their homesteads and villages of birth. Thus, small towns play an important role for both short-term and more-settled residents, and offer opportunities to become urban without the crowding of large cities. On the other hand, the opportunities available to young people and independent women should not be praised uncritically, as many of them are living very uncertain and precarious lives (see also the discussion in [21]).

The preceding analysis illustrates the ways in which these two small towns have become places that combine rural and urban living by continuously including the proximate agriculturally-based livelihood opportunities with urban-like economic and social options. Although the demographic transitions could support this, neither of the small towns have been fully acknowledged as urban centres, and they are therefore not counted in Tanzania's official statistics of urbanization. Such continuous rural-urban transitions can be read as the result of co-existing dynamics, such as increased accessibility related to road constructions, favourable rural economies that produce economic surpluses, the densification of housing and people, and the tangible rural-urban linkages. This interpretation is in line with seminal studies of small town development that define small towns by their functions, rather than their size and/or official role [23]. However, the argument of this paper is that small town transition is also moulded by residents' and migrants' actions, visions and aspirations for these locations to become urban and provide for urban living. In this way, rural-urban transitions are produced, lived through, and formed by collective and individual interpretations, visions, and aspirations-what we refer to as the simultaneous production and expression of urbanism.

\section{Conclusions}

Tanzania's urban population is predicted to quadruple from 15 million in 2020 to 60 million in 2050 [62]. Such enormous spatial and demographic changes present formidable planning challenges. In a recent report, the Coalition for Urban Transitions (CUT) discusses how this development will require new policy frameworks; institutional arrangements; effective and inclusive land-use planning; public investments in, for example, infrastructure; and a governance approach that prioritizes urbanization [62]. Surprisingly, 
however, the CUT mainly focuses on urbanization in larger agglomerations. This is most unfortunate, because, as was concluded in recent analyses of Tanzania's urbanization [69] and in the Sahelian and West Africa Group's (SWAC) recent synthesis report, much of Africa's urbanisation is taking place in and around small towns and intermediate cities [4]. In their report, SWAC shows how the distinctions between rural and urban are blurring, and with this new reality, it is argued that "we are obligated to rethink the way in which governance systems are established" [70].

The preceding analyses of rural-urban transitions in Madizini and Ilula are examples of this process, and they clearly illustrate the ways in which urbanization and urbanism are taking form between villages and towns. Thus, insights from these processes can provide relevant starting points for the rethinking of governance systems towards sustainable urbanization. Reflecting first on the role of local leaders and community groups, our analysis illuminated how they, for a long time, have been pushing for an administrative transition from village to town. In this way, Madizini and Ilua can take over full governance responsibilities from the respective (rural) districts (see also the discussion in [28]). Such administrative transitions can be important starting points for the better involvement of small town dwellers in the formation of urbanization processes. Compared to district officials, they will probably be better positioned to address the incremental transition from rural to urban, and to respond to local needs for employment, housing and access to services, and residents' aspirations of becoming urban. For this transition to be successful, however, crucial finances and administrative expertise need to be devolved from the district level to the local governments of small towns. Also, as our analysis has revealed, it needs to be considered that urbanization and urbanism are not uniform processes. Different population groups are producing and identifying themselves with the rural and urban mixture of life in various ways, based on their opportunities (or lack of them), aspirations and visions. If the small towns shall be successful in further developing sustainable livelihood opportunities for such diverse groups of dwellers, local governance will need to secure the inclusion of these groups' needs and voices. This involves gender-sensitive planning in order to ensure positive livelihood options for independent women in small towns, and the embracement of huge temporary population groups, not least young men and women who are trying to establish independent lives. Such an inclusion will not happen automatically, but rather will depend on the development of human resources, e.g., the training and education of local politicians, administrators and citizens. For such transitions of governance systems to happen, collaboration between various scales of planning and policy will be needed. As Watson asserts, urban planning in response to local needs is not solely a local issue, but rather depends on moral reasoning, where public interests are also national interests [8]. Likewise, Simon warns against naïve expectations regarding the devolution of governance to the local level based on promotions of local planning as a substitute to the absence of the state [59].

The emerging urbanization and urbanism between villages and towns in Sub-Saharan Africa are outcomes of larger economic and demographic processes. However, as our analysis has shown, people's livelihood practices, aspirations and agency are important drivers of the ways in which these processes unfold (see also [19-21,23,44]). Small towns could very well be important 'urban' alternatives to larger cities for sustainable urbanisation in Sub-Saharan Africa [5]. However, for this to be a successful policy, engagements and commitments at all levels of governance are needed, and will involve the visions, aspirations and actions of small town residents. Ultimately, we argue that our study establishes an important starting point for further explorations of the role of the simultaneous production and expression of urbanism in small town urbanization.

Author Contributions: Conceptualization, J.A.; methodology, J.A. and T.B.-T.; investigation, J.A., S.K. and T.B.-T.; formal analysis, J.A., S.K. and T.B.-T.; writing-original draft preparation, J.A.; review and editing, J.A., S.K. and T.B.-T.; visualization, T.B.-T. All authors have read and agreed to the published version of the manuscript. 
Funding: The research and fieldwork were supported by two grants from the Consultative Research Committee for Development Research of the Danish Ministry of Foreign Affairs: grant no. 09-P11Tanzania (2010) and grant no. 13-P02-TAN (2014).

Institutional Review Board Statement: no statement.

Informed Consent Statement: Informed consent was obtained from all subjects involved in the study.

Data Availability Statement: Data are available on request from the correspondence with the corresponding author.

Acknowledgments: This project has been coordinated by the School of Agricultural Economics and Business Studies, Sokoine University of Agriculture, Tanzania, and implemented in partnership with the Department of Geosciences and Natural Resource Management, Section for Geography, University of Copenhagen, Denmark. We would like to thank our collaborating research colleagues and participants in the study sites. In addition, we would like to thank the four anonymous reviewers for their thoughtful and valuable comments.

Conflicts of Interest: The authors declare no conflict of interest.

\section{Appendix A}

Distribution of the sampled households in the two study sites Madizini and Ilula - 2016.
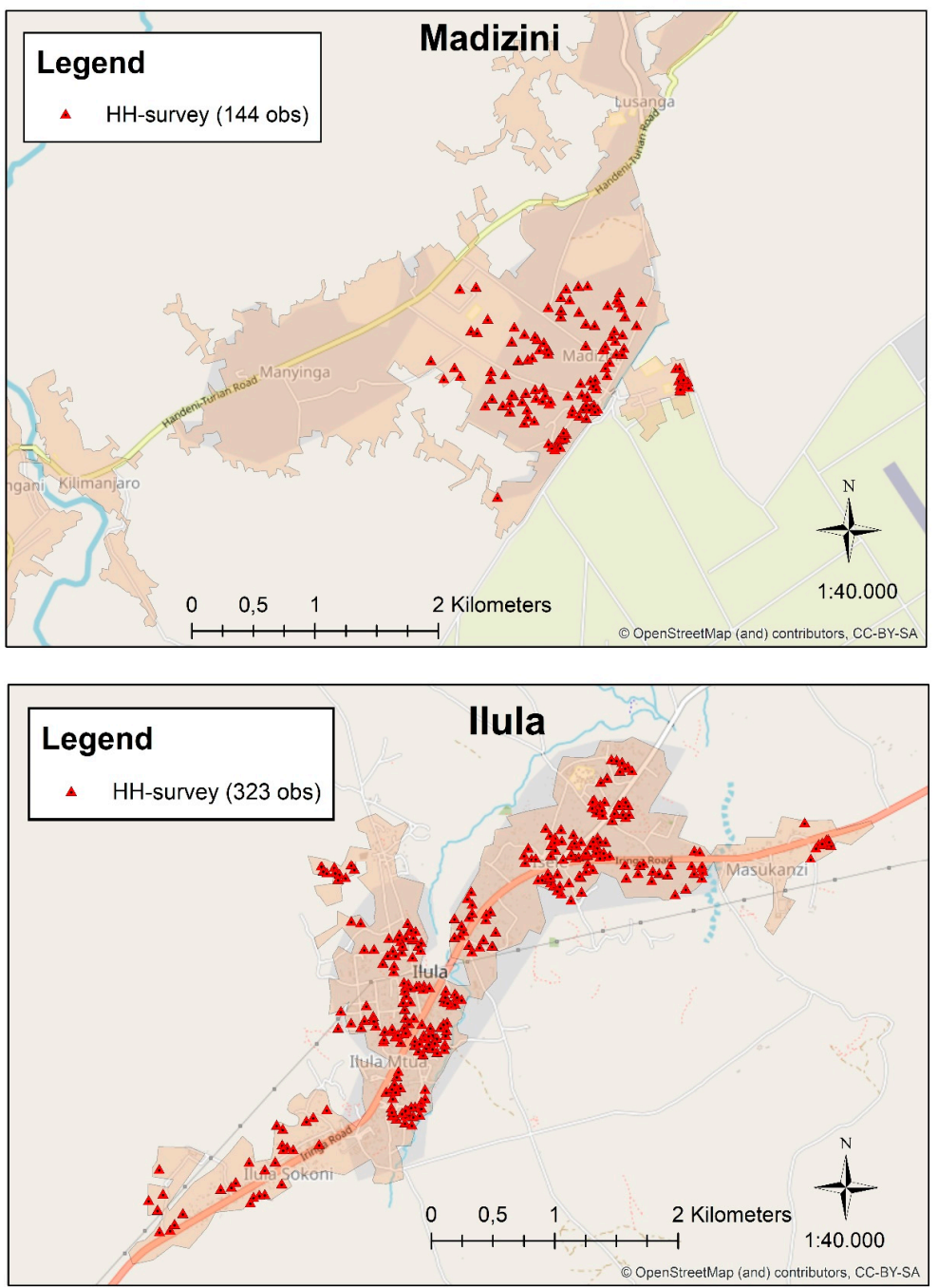


\section{Appendix B}

From village to Township; 1977-2016

In 1977 Ilula was three separate villages (Sokoine, Ilula and Itunda) along the Tan-Zam highway.

This pattern of settlement was still dominant in 1995 . From the early 2000 s to 2015 the settlement expanded and 'grew together'.

Method:

- The rural settlement was classified by using Landsat (30 meters) and Sentinel-2 (10 meters) optical and near-infrared bands and Random Forest classifier via Google Earth Engine.

- For each year of 1995, 2005, 2015 (Landsat) and 2015 (Sentinel-2), the composite mosaic was created by taking the median value of all available images with cloud cover $<10 \%$ for each band.

- A total of 600 points were manually sampled for three classes (settlement, vegetation and bare land) by using the true-color visuals.
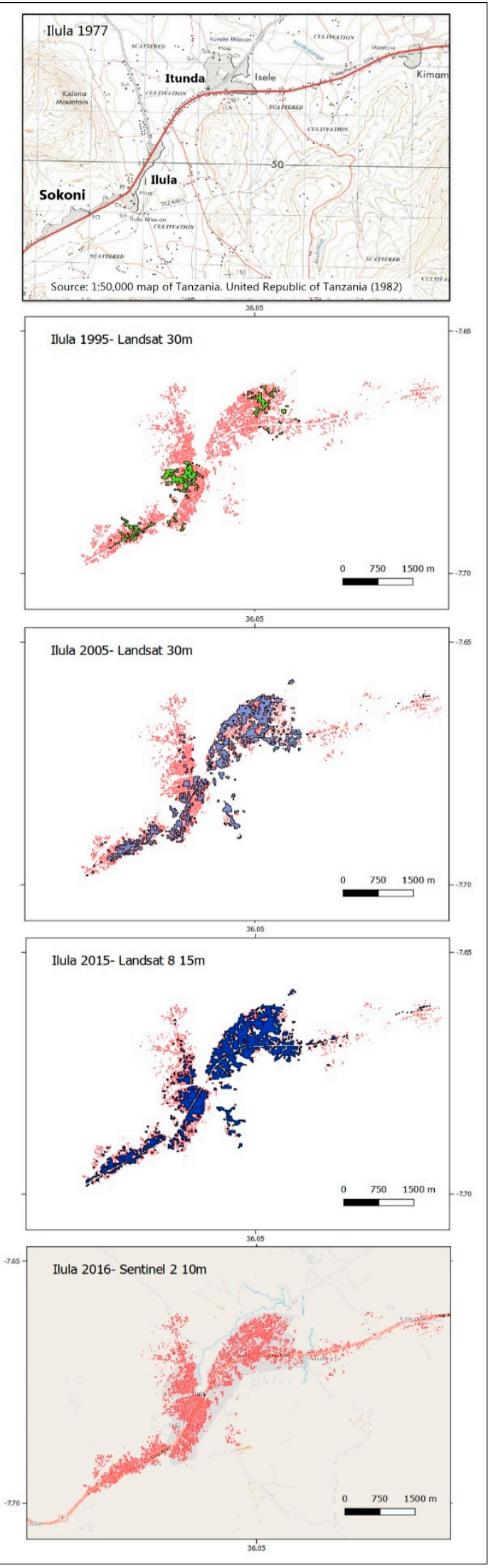


\section{References}

1. United Nations; Department of Economic and Social Affairs; Population Division. World Population Prospects Highlights, 2019 Revision Highlights, 2019 Revision; Department of Economic and Social Affairs: New York, NY, USA, 2019; ISBN 978-92-1-148316-1.

2. Angel, S. Making Room for a Planet of Cities. In The City Reader, 7th ed.; Routledge Urban Reader Series; LeGates, R.T., Stout, F., Eds.; Routledge: Abingdon, UK; New York, NY, USA, 2020; pp. 665-677. ISBN 978-0-429-26173-2.

3. United Nations. The World's Cities in 2016; Statistical Papers-United Nations (Series A), Population and Vital Statistics Report; United Nations: New York, NY, USA, 2016; ISBN 978-92-1-362000-7.

4. OECD; Sahel and West Africa Club. Africa's Urbanisation Dynamics 2020: Africapolis, Mapping a New Urban Geography; West African Studies; OECD: Paris, France, 2020; ISBN 978-92-64-57958-3.

5. UCLG. Fourth Global Report on Decentralization and Local Democracy. Co-Creating the Urban Future: The Agenda of Metropolises, Cities and Territories; United Cities and Local Governments: Barcelona, Spain, 2017.

6. Curiel, R.P.; Heinrigs, P.; Heo, I. Cities and Spatial Interactions in West Africa; OECD: Paris, France, 2017.

7. Denis, E.; Zérah, M.-H. Subaltern Urbanisation in India: An Introduction to the Dynamics of Ordinary Towns; Springer: Berlin, Germany, 2017; ISBN 81-322-3616-5.

8. Watson, V. Locating planning in the New Urban Agenda of the urban sustainable development goal. Plan. Theory 2016, 15, 435-448. [CrossRef]

9. Schindler, S. Towards a paradigm of Southern urbanism. City 2017, 21, 47-64. [CrossRef]

10. Van Vliet, J.; Birch-Thomsen, T.; Gallardo, M.; Hemerijckx, L.-M.; Hersperger, A.M.; Li, M.; Tumwesigye, S.; Twongyirwe, R.; van Rompaey, A. Bridging the rural-urban dichotomy in land use science. J. Land Use Sci. 2020, 15, 585-591. [CrossRef]

11. Derickson, K.D. Urban geography I: Locating urban theory in the 'urban age'. Prog. Hum. Geogr. 2015, 39, 647-657. [CrossRef]

12. Brenner, N. New Urban Spaces: Urban Theory and the Scale Question; Oxford University Press: Oxford, UK, 2019; ISBN 978-0-19062721-8.

13. Brenner, N.; Schmid, C. Towards a new epistemology of the urban? City 2015, 19, 151-182. [CrossRef]

14. Pieterse, E. Grasping the unknowable: Coming to grips with African urbanisms. Soc. Dyn. 2011, 37, 5-23. [CrossRef]

15. Pieterse, E. Introduction: Rogue urbanisms. Soc. Dyn. 2011, 37, 1-4. [CrossRef]

16. Bell, D.; Jayne, M. Small Cities? Towards a Research Agenda. Int. J. Urban Reg. Res. 2009, 33, 683-699. [CrossRef]

17. Lacour, C.; Puissant, S. Re-Urbanity: Urbanising the Rural and Ruralising the Urban. Environ. Plan A 2007, 39, 728-747. [CrossRef]

18. Christiaensen, L.; De Weerdt, J.; Kanbur, R. Urbanization and Poverty Reduction: The Role of Secondary Towns in Tanzania; Universiteit Antwerpen, Institute of Development Policy and Management (IOB): Antwerpen, Belgium, 2016.

19. Bryceson, D.F. Birth of a market town in Tanzania: Towards narrative studies of urban Africa. J. East. Afr. Stud. 2011, 5, 274-293. [CrossRef]

20. De Weerdt, J. Moving out of poverty in Tanzania: Evidence from Kagera. J. Dev. Stud. 2010, 46, 331-349. [CrossRef]

21. Cottyn, I. Between Modern Urbanism and "Rural" Realities: Rwanda's Changing Rural-Urban Interface and the Implications for Inclusive Development. Ph.D. Thesis, University of Utrecht, Utrecht, The Netherlands, 2020.

22. Steel, G.; Birch-Thomsen, T.; Cottyn, I.; Lazaro, E.A.; Mainet, H.; Mishili, F.J.; van Lindert, P. Multi-activity, multi-locality and small-town development in Cameroon, Ghana, Rwanda and Tanzania. Eur. J. Dev. Res. 2019, 31, 12-33. [CrossRef]

23. Agergaard, J.; Tacoli, C.; Steel, G.; Ørtenblad, S.B. Revisiting Rural-Urban Transformations and Small Town Development in Sub-Saharan Africa. Eur. J. Dev. Res. 2019, 31, 2-11. [CrossRef]

24. Scoones, I.; Murimbarimba, F. Small towns and land reform in Zimbabwe. Eur. J. Dev. Res. 2020. online ahead of print. [CrossRef] [PubMed]

25. Tacoli, C.; Agergaard, J. Urbanisation, Rural Transformation and Food Systems: The Role of Small Towns; Working Paper: Rural-Urban Transformation and Food Systems; IIED: London, UK, 2017.

26. Larsen, M.N.; Birch-Thomsen, T. The role of credit facilities and investment practices in rural Tanzania: A comparative study of Igowole and Ilula emerging urban centres. J. East. Afr. Stud. 2015, 9, 55-73. [CrossRef]

27. Lazaro, E.; Agergaard, J.; Larsen, M.N.; Makindara, J.; Birch-Thomsen, T. Rural Transformation and the Emergence of Urban Centres in Tanzania; Department of Geosciences and Natural Resource Management, University of Copenhagen: Copenhagen, Denmark, 2017; p. 35.

28. Lazaro, E.; Agergaard, J.; Larsen, M.N.; Makindara, J.; Birch-Thomsen, T. Urbanisation in Rural Regions: The Emergence of Urban Centres in Tanzania. Eur. J. Dev. Res. 2019, 31, 72-94. [CrossRef]

29. Delgado-Campos, J.; Naxhelli, R. Rurbanization in the Regional Periphery of Central Mexico. In Human Settlement Development; EOLSS Publishers/UNESCO: Paris, France, 2009; ISBN 978-1-84826-045-0.

30. Guin, D. From Large Villages to Small Towns: A Study of Rural Transformation in New Census Towns, India. Int. J. Rural Manag. 2018, 14, 1-23. [CrossRef]

31. Bartels, L.E.; Bruns, A.; Simon, D. Towards Situated Analyses of Uneven Peri-Urbanisation: An (Urban) Political Ecology Perspective. Antipode 2020, 52, 1237-1258. [CrossRef]

32. Keil, R. After Suburbia: Research and action in the suburban century. Urban Geogr. 2020, 41, 1-20. [CrossRef]

33. McGee, T. The Spatiality of Urbanization: The Policy Challenges of Mega-Urban and Desakota Regions of Southeast Asia; United Nations University: Tokyo, Japan, 2009; p. 40.

34. Vidovich, L.D. Suburban studies: State of the field and unsolved knots. Geogr. Compass 2019, 13, e12440. [CrossRef] 
35. Christiaensen, L.; Todo, Y. Poverty Reduction During the Rural-Urban Transformation-The Role of the Missing Middle. World Dev. 2014, 63, 43-58. [CrossRef]

36. Satterthwaite, D. Outside the Large Cities; The Demographic Importance of Small Urban Centres and Large Villages in Africa, Asia and Latin America; IIED: London, UK, 2006.

37. Tacoli, C. Urbanisation and migration in Sub-Saharan Africa: Changing patterns and trends. In Mobile Africa: Changing Patterns of Movement in Africa and Beyond; De Bruijn, M., van Dijk, R., Eds.; Brill: Leiden, The Netherlands, 2001; pp. 141-152.

38. Tacoli, C. The Earthscan Reader in Rural-Urban Linkages; Earthscan: London, UK, 2006; ISBN 1-84407-316-5.

39. Cottyn, I. Small towns and rural growth centers as strategic spaces of control in Rwanda's post-conflict trajectory. J. East. Afr. Stud. 2018, 12, 329-347. [CrossRef]

40. Baker, J. State, Governance and the Creation of Small Towns in Ethiopia. Eur. J. Dev. Res. 2019, 31, 34-52. [CrossRef]

41. Tacoli, C. The links between urban and rural development. Environ. Urban. 2003, 15, 3-12. [CrossRef]

42. Bryceson, D.F. Deagrarianization and rural employment in sub-Saharan Africa: A sectoral perspective. World Dev. 1996, 24, 97-111. [CrossRef]

43. Bryceson, D.F. African rural labour, income diversification \& livelihood approaches: A long-term development perspective. Rev. Afr. Political Econ. 1999, 26, 171-189. [CrossRef]

44. Steel, G.; van Lindert, P. Rural Livelihood Transformations and Local Development in Cameroon, Ghana and Tanzania; Working Paper: Rural-Urban Transformation and Food Systems; IIED: London, UK, 2017.

45. Zoomers, A. Globalisation and the foreignisation of space: Seven processes driving the current global land grab. J. Peasant Stud. 2010, 37, 429-447. [CrossRef]

46. Rigg, J. An Everyday Geography of the Global South; Routledge: London, UK; New York, NY, USA, 2011.

47. Kelly, P.F. Migration, Agrarian Transition, and Rural Change in Southeast Asia. Crit. Asian Stud. 2011, 43, 479-506. [CrossRef]

48. Mercer, C.; Page, B.; Evans, M. Development and the African Diaspora; Zed Books: London, UK, 2008.

49. Zoomers, A.; Leung, M.; van Westen, G. Local Development in the Context of Global Migration and the Global Land Rush: The Need for a Conceptual Update. Geogr. Compass 2016, 10, 56-66. [CrossRef]

50. Page, B.; Sunjo, E. Africa's middle class: Building houses and constructing identities in the small town of Buea, Cameroon. Urban Geogr. 2018, 39, 75-103. [CrossRef]

51. de Brauw, A.; Mueller, V.; Lee, H.L. The Role of Rural-Urban Migration in the Structural Transformation of Sub-Saharan Africa. World Dev. 2014, 63, 33-42. [CrossRef]

52. Kaag, M.; Baltissen, G.; Steel, G.; Lodder, A. Migration, Youth, and Land in West Africa: Making the Connections Work for Inclusive Development. Land 2019, 8, 60. [CrossRef]

53. Ørtenblad, S.B.; Birch-Thomsen, T.; Msese, L.R. Rural Transformation and Changing Rural-Urban Connections in a Dynamic Region in Tanzania: Perspectives on Processes of Inclusive Development. Eur. J. Dev. Res. 2019, 31, 118-138. [CrossRef]

54. Wineman, A.; Liverpool-Tasie, L.S. Land markets and migration trends in Tanzania: A qualitative-quantitative analysis. Dev. Policy Rev. 2018, 36, O831-O856. [CrossRef]

55. Nijenhuis, K. Farmers on the Move: Mobility, Access to Land and Conflict in Central and South Mali. Ph.D. Thesis, Wageningen University \& Research, Wageningen, The Netherlands, 2013.

56. Büscher, K.; Mathys, G. War, Displacement and Rural-Urban Transformation: Kivu's Boomtowns, Eastern D.R. Congo. Eur. J. Dev. Res. 2019, 31, 53-71. [CrossRef]

57. Mathys, G.; Büscher, K. Urbanizing Kitchanga: Spatial trajectories of the politics of refuge in North Kivu, Eastern Congo. J. East. Afr. Stud. 2018, 12, 232-253. [CrossRef]

58. Reeves, M. Infrastructural Hope: Anticipating 'Independent Roads' and Territorial Integrity in Southern Kyrgyzstan. Ethnos 2017, 82, 711-737. [CrossRef]

59. Simon, D. Uncertain times, contested resources: Discursive practices and lived realities in African urban environments. City 2015, 19, 216-238. [CrossRef]

60. Anh, N.T.; Rigg, J.; Huong, L.T.T.; Dieu, D.T. Becoming and being urban in Hanoi: Rural-urban migration and relations in Viet Nam. J. Peasant Stud. 2012, 39, 1103-1131. [CrossRef]

61. Cockx, L.; Colen, L.; De Weerdt, J. From corn to popcorn? Urbanization and dietary change: Evidence from rural-urban migrants in Tanzania. World Dev. 2018, 110, 140-159. [CrossRef]

62. Worrall, L.; Colenbrander, S.; Palmer, I.; Makene, F.; Mushi, D.; Kida, T.; Martine, M.; Godfrey, N. Better Urban Growth in Tanzania: Preliminary Exploration of the Opportunities and Challenges; Coalition for Urban Transitions: London, UK; Washington, DC, USA, 2017; p. 90.

63. Kironyi, L. The Role of Governance Structures and Practices Related to Land, Water and Waste in Supporting Transformation of Ilula and Madizini Emerging Urban Centres, Tanzania. Ph.D. Thesis, Sokoine University, Morogoro, Tanzania, University of Copenhagen, Copenhagen, Denmark, 2020.

64. Nyaki, S.A. Business Development and the Role of Social Networks in Business Investment and Employment Creation in Tanzania's Emerging Urban Centres. Ph.D. Thesis, Sokoine University, Morogoro, Tanzania, University of Copenhagen, Copenhagen, Denmark, 2020.

65. NBS. Tanzania Population and Housing Census: Population Distribution by Administrative Areas; National Bureau of Statistics: Dodoma, Tanzania, 2013. 
66. Beckham, S.W.; Shembilu, C.R.; Winch, P.J.; Beyrer, C.; Kerrigan, D.L. 'If you have children, you have responsibilities': Motherhood, sex work and HIV in southern Tanzania. Cult. Health Sex. 2015, 17, 165-179. [CrossRef] [PubMed]

67. Folkers, A.S.; van Buiten, B.A.C. Turiani Hospital. In Modern Architecture in Africa: Practical Encounters with Intricate African Modernity; Folkers, A.S., van Buiten, B.A.C., Eds.; Springer International Publishing: Cham, Switzerland, 2019; pp. $248-258$. ISBN 978-3-030-01075-1.

68. Burchardt, M. Belonging and Success: Religious Vitality and the Politics of Urban Space in Cape Town; Brill: Leiden, The Netherlands, 2013; pp. 167-187. ISBN 978-90-04-24907-3.

69. Wenban-Smith, H. Population Growth, Internal Migration, and Urbanisation in Tanzania, 1967-2012; Working Paper; International Growth Centre, London School of Economics: London, UK, 2015.

70. Mayaki, I.A. Comment to the SWAC/OECD Report. Available online: http://www.oecd.org/africa-urbanisation/\#policy-makers (accessed on 10 January 2021). 